\title{
Research on Financial Management Objectives from the Perspective of Corporate Governance Structure
}

\author{
Zhifeng $\mathrm{Jie}^{1, \text { a }}$ \\ ${ }^{1}$ School of Accounting, Nanchang Institute of Science \& Technology, Nanchang, Jiangxi, China, \\ 330108 \\ ${ }^{\mathrm{a} e m a i l,}$
}

Keywords: Financial Management Objectives, Corporate Governance Structure

\begin{abstract}
There is an inseparable relationship exists between corporate governance structure and financial management objectives. Choosing what kind of financial management objectives largely depends on the company's governance structure, and in turn the company's governance structure also affects the finally realization of company's financial management objectives. With the development and changes of corporate governance, financial management objectives will change. In this paper, after a variety of financial management objectives were introduced, combined with the company's governance structure and level, analysis its effects on selection of financial management objectives and prospects for its future development.
\end{abstract}

\section{Introduction}

Corporate governance is the most important modern enterprise system architecture. Modern Enterprise System is different from the fundamental point is the separation of ownership and management rights, that is, to between the owner and operator of the formation mechanism of checks and balances for the enterprise management and control. Modern enterprise corporate governance structure is such a mechanism for a coordinated shareholders and other stakeholders relations, which involves a wide range of content and other incentives and constraints, simply put, it is to deal with the corporate governance structure of enterprises of various contracts a system of relations. Financial management, management system as an important corporate governance framework in existence and operation, which directly reflects the change in the target financial environment, and changes in the environment need to be appropriately adjusted. Logic of corporate governance has changed, or that the company's goal has changed, as the financial operation driven financial management objectives must change accordingly. Different financial management objectives will produce different financial management mechanism. Deep understanding of the core of corporate governance structure of the modern enterprise system, a correct understanding of the logic of corporate governance, financial management and thus determine the scientific goals for optimizing the behavior of corporate finance, financial management to achieve a virtuous cycle, it is of great practical significance.

\section{Concepts of Corporate Governance Structure}

Corporate governance is to establish incentive and restraint mechanisms between the principal and the agent through the company's internal decision-making and implementation mechanisms. Corporate governance structure includes three aspects: First, the governance body, that is, who participate in governance, modern governance structure that corporate governance is the main stakeholder; the second is the object of governance or management objects, focus on solving the governance structure Stakeholders the relationship between rights and responsibilities, particularly the distribution of residual claims and control rights, in order to ensure a stable and cooperative relations, each stakeholder must be supervised by, the rights of the other constraints, it is necessary to share the resource allocation decisions, these rights are control; third is the means of governance for the corporate governance structure, to achieve a reasonable residual claims and control rights, must possess the necessary procedures and mechanisms, such as voting procedures, the distribution 
of benefits programs, personnel appointment and removal procedures and general meeting of shareholders, board of supervisors and managers and other institutions.

\section{Related Research on Financial Management}

Financial management is the corporate governance framework in existence and operation of a key management system that can organize the company's financial operations, to deal with the interests of all sides. The goal of financial management is the enterprise under certain circumstances and conditions, financial management should be to achieve the desired results and the basic requirements. It is the guide and the standard of financial management, determines the principles, procedures and methods used in financial management, the logical starting point is to establish a financial management system. It is the starting point and destination of corporate financial management activities for all financial activities have a fundamental impact on the financial management is the connection link between theory and practice. In general, it is for having a role in guiding enterprises, incentives, unifying role and assessment role. Different financial management objectives will produce different financial management mechanism. Fundamentally speaking, the goal of financial management depends on the company's goals, objectives and business objectives of financial management are consistent.

The objective of financial management is a direct reflection of the changing financial environment, and must be appropriately adjusted according to changes in the financial environment. That is, if a logical corporate governance changes, then run as a financial driving force for financial management objectives is also bound to vary accordingly. Financial management objectives only with the corporate governance structure to adapt, it can be called the most reasonable financial goals. We must deeply understand the corporate governance structure, a correct understanding of the logic of corporate governance, and thus scientifically determine the financial management objectives on this basis, it can not only optimize the company's financial behavior, while also helping to achieve a virtuous circle of financial management.

\section{Effect of the Corporate Governance Structure on the Financial Management Target}

The corporate governance structure of the company's financial management system operating environment forms the basis. Financial management is a management system occupies a very important and special status of the subsystem, which covers a wide range, comprehensive, high sensitivity, for any one company's management can not as comprehensive as the financial management firm grasp the inputs and outputs. Modern enterprise's financial activities, including fund-raising, serving, operating, distribution and other sectors, therefore, the nature of the company's financial management is to finance the activities of management, it is a direct manifestation of the subjective to the objective of the reaction, the performance of financial management activities of the main elements subjective elements of object behavior, which requires financial management activities of the main elements should be in accordance with the established goals of object elements to exercise control and operation.

The corporate governance structure is the determinant of the financial management system structure and its main elements. Entity's financial management activities refers to the exercise of financial activities by the management of the companies who, in the framework of corporate governance stakeholders governance, the main interest in the corporate governance structure should be diverse, including not only shareholders, but also including creditors, employees, suppliers, customers, clients and government and corporate economic interests of stakeholders. The economic benefits of these benefits subject requirements, must be by means of the company's financial activities to achieve, which determines the main elements of the company's financial management activities, shall be the main interests of the corporate governance structure, namely: "stakeholder" to share. This means that we must establish a stakeholder to participate in the financial management system management, therefore, should be based on Hyundai's corporate governance structure, the main elements of financial management activities were given general meeting of shareholders, 
board of directors, a professional financial manager, enterprise workers internal governance; by banks, the government, represented by the external governance and corporate influence and control the operation of the financial management system from a stakeholder perspective. Between inside and outside the two main elements of both independent of each other, mutual checks and balances, but also mutual coordination and promotion, in order to ensure the continuous exchange of information and material, making financial interests and demands of all stakeholders can be achieved, and financial management system to healthy and efficient development.

\section{The Status of Corporate Governance Structure}

From the point of view of the status quo of corporate governance, corporate governance is a unified internal governance and external governance, including internal governance in certain circumstances constitute the core of corporate governance, and external governance under certain conditions, it can be converted to internal governance, internal governance and external governance complement each other, jointly completed a corporate governance objectives. Therefore, analysis of the current status of corporate governance, two aspects should be from internal governance and external governance.

First, the effectiveness of the internal governance mechanisms can be reflected in three aspects, namely: effectiveness of oversight mechanisms and incentives for decision-making mechanism. Current state-owned holding company of internal governance than the average state-owned enterprises to improve much, but there are still aspects of the above three issues: the case of (1) state-owned shares dominance, on behalf of the owner of serious absence, the shareholders Assembly-existent, many of the actual terms of reference shareholders' meeting is very limited, and there is a tendency to weaken and become formalized, and therefore as a government body equity capital can not form an effective oversight and control of the enterprise; (2) the operator incentive and restrictive incompatible, both the operators lack of effective incentive, but also a lack of effective control. Since the shareholders' meeting and the Supervisory Board supervised the weakened state-owned enterprise managers can more through in-service and other forms of consumption, to expand their actual level of benefits, such as more housing, private car, the use of public funds to eat and drink, entertainment, tourism Wait.

Second, the effectiveness of external governance, the effectiveness can be achieved by competitive markets outside the enterprise to judge. The effectiveness of governance by the external competitive external markets such as: credit markets, capital markets, manager of market development constraints. Several aspects of this, our country there are also obvious defects, such as: Marketing Manager influenced by traditional personnel system has not really taken shape, underdeveloped capital markets, mergers and bankruptcies mechanism is not yet perfected.

In short, the current system of state-owned companies in the internal corporate governance does not really reflect the connotation of modern corporate governance structure operating mechanism, but instead with a more administrative works. On the external governance, due to external competitive market has not really set up, resulting in external governance mechanism blur, no external pressure on the management, no internal motivation to improve company operations. Therefore, it can be said that China has yet to establish a good corporate governance structure, it should be said that the current corporate governance structure of China, has significant "internal government intervention under control" feature, the board of directors, board of supervisors, managers, in order to pursue personal self-interest, to use their power at hand with the government game, the result of state-owned assets in the assessment, in the context of the transaction, in decision-making and even great loss in insolvency, serious damage, including the national and individual within the interests of investors. Financial management activities of the enterprise, due to the special nature of the impact of corporate governance model, in determining the methods and procedures, financing and capital structure of financial decisions, investment decisions, dividend distribution and Financial Management performance targets on both a unique form of activity. 


\section{The Policy of Improving the Corporate Governance Structure and Clearing the Scientific Financial Management Objective}

In recent years China has been working to improve and perfect the business operations of the government incentives and constraints, namely to ensure that state-owned assets from the point of view to build the governance structure of state-owned enterprises, the specific performance of the government has the right to appoint and dismiss managers, corporate control major decisions, supervision of operators behavior. Visible, to maximize the interests of the owner or maximize shareholder wealth become the basic standard enterprise system efficiency. Such reform ideas can be broadly described as a "shareholder first" control logic. However, since the government far beyond the exercise of the functions of the owner of the enterprise, not on behalf of the owner of the enterprise, not only incentive and restraint mechanisms ultimately difficult to form, and combined with the power of the state capital and the government so that the operator can arbitrarily deprive other minority shareholders and creditors interests of enterprise employees should participate in decision-making, supervision is often a mere formality because the workers' congress is difficult to actually play a role.

Corporate governance structure affected by economic, social and historical traditions and national policies and other factors, there is no standard model. Construction of the corporate governance structure of both existing practices can not simply be transplanted overseas, we can not ignore some of the basic principles of universality has been, especially in line with the inherent requirements of a modern market economy "common governance" logic. Corporate governance structure is to form such a structure: the owner of the legal form into the enterprise through the exercise of functions within the enterprise by the authority, decision-making bodies, supervisory bodies and enforcement agencies, to protect the owners of the enterprise's ultimate control over the formation of the owner between the operators and workers incentives and checks and balances, and through the establishment of a scientific leadership system, decision-making procedures and accountability, so that rights are guaranteed each other's behavior is constrained. Specifically, it is to understand the structure of corporate governance as the core of the company's development, based on the understanding that good corporate governance is a key element to improve operational efficiency, and then set up the shareholders, between board of directors, managers, employees and other stakeholders' interrelationships.

\section{Conclusion:}

There is no standard set of line with the corporate governance structure, there is no scientific management to meet the target of a series of financial management in particular, the modern enterprise system can not really established, economic stability can not be improved. To recognize the financial management of the target due to the development of corporate governance structure should change, and then through the financial management activities increase corporate value to satisfy the interests of stakeholders, and to maintain sustainable development of enterprises significant.

\section{References}

[1] Jia Xinzhang, Li Jingyuan. Finance and Accounting, Vol. 6 (2014) No 53, p.25-26

[2] Peng Sue, Wang Yunhui, Wang Qunyong. Economist, Vol. 12 (2015) No 27, p.74-76

[3] Qian Xiyuan, Jing Jianfen, Hou XuSiem. Accounting, Vol. 30 (2014) No 19, p.144-145

[4] Wang Kuailiang. Modern Industry, Vol. 29 (2011) No 27, p.21-23

[5] Zhang Gongxu, Sun Jing. Market Modernization, Vol. 8 (2013) No 27, p.57-60 